\title{
Changes of Antibody Associated with Cell-Mediated Immunity in College Students During Two Years after Rubella Vaccination
}

Kihei Terada*, Kimiko Hagihara, Yuhei Tanaka, Hideto Teranishi, Tomohiro Oishi, Ippei Miyata, Satoko Ogita, Naoki Ohno and Kazunobu Ouchi Kawasaki Medical School, Department of Pediatrics, 577 Matsushima, Kurashiki, Okayama Prefecture, 701-0192, Japan

*Corresponding author: Kihei Terada, Kawasaki Medical School, Department of Pediatrics, 577 Matsushima, Kurashiki, Okayama Prefecture, 701-0192, Japan, Tel: +81-86-462-1111; Fax: +81-86-462-1199; E-mail: kihei@med.kawasaki-m.ac.jp

Received date: November 13, 2017; Accepted date: November 16, 2017; Published date: November 23, 2017

Copyright: $\subseteq 2017$ Terada K, et al. This is an open-access article distributed under the terms of the Creative Commons Attribution License, which permits unrestricted use, distribution, and reproduction in any medium, provided the original author and source are credited.

\begin{abstract}
Objective: This study measured cell-mediated immunity (CMI) and serum antibody levels against rubella to clarify antibody changes associated with CMI during 2 years after vaccination.

Methods: The study subjects were 64 college students in two groups: 38 subjects who (having exhibited hemagglutination-inhibition $(\mathrm{HI})$ anti-rubella antibody titers of $\leq 1: 16)$ had been vaccinated with a rubella vaccine 2 years previously (Group 1); and 26 subjects who (having exhibited $\mathrm{HI}$ titers $\geq 1: 32$ ) had not been vaccinated 2 years previously (Group 2). All students were tested for IgG antibody levels (by enzyme-linked immunosorbent assay) and CMI (by interferon-y (IFN-y release assay).

Results: The IgG antibody and IFN-y values decreased significantly in Group 1 during the 2 years postvaccination, while antibody titers in Group 2 did not decrease over this interval. The proportion of Group-1 individuals with $\mathrm{HI}$ antibody titers $\leq 1: 16$ increased to $27 / 38(71.1 \%)$ at two years following vaccination, compared with 6/26 (23.1\%) in Group 2. No correlation of IgG antibody titers was observed in Group 1 between one month and two years after vaccination. However, a strong correlation $(r=0.85, p<0.00001)$ was detected in Group 2 between two years ago and the present. The correlation of IFN- $y$ values in Group 1 between one month and two years after vaccination was $0.614(p<0.00005)$. When the subjects were classified by CMI status, the numbers of individuals who were intermediate and negative for $\operatorname{lgG}$ antibody at two years after vaccination were 1 and 0 of 13 subjects, 3 and 1 of 9 subjects, and 3 and 2 of 16 subjects in Group 1, respectively, while the antibody-positive status was maintained in all subjects in Group 2.
\end{abstract}

Conclusion: The IgG antibody and IFN- $\gamma$ values decreased in distinct ways during the 2 years of the study; the persistence of the seropositivity was associated with CMI status.

Keywords: Cell-mediated immunity; Interferon- $\gamma$ release assay; Antibody; Plasma cells; Reinfection

\section{Introduction}

Rubella virus is a member of the genus Rubivirus and belongs to the family Togaviridae. Although rubella is a relatively mild disease, rubella infection in pregnant mothers can lead to problems with congenital rubella syndrome (CRS) in the fetus. In Japan, the rubella vaccine was administered only to female junior high school students between 1977 and 1994, with the goal of preventing the occurrence of CRS in prospective offspring (rather than the goal of eliminating rubella epidemics). The Japanese NIH estimated that approximately 0.7 and 4.5 million female and male adults (respectively) of reproductive age remained susceptible as of 2003 [1], given the failure to perform catch-up vaccination in this cohort. Instead, measurement of rubella antibody titers has been recommended as a means for identifying vaccination candidates in Japan. Such a screen would be valuable as a part of antenatal screening; vaccination of susceptible individuals would prevent CRS at next pregnancy, and vaccination of susceptible medical and nursing students or new hospital workers would prevent nosocomial infection. Generally speaking, individuals who test positive for anti-rubella antibody (by hemagglutination- inhibition (HI) assay or enzyme-linked immunosorbent assay (ELISA)) are immune. However, there have been many reports regarding subjects who had previously tested antibody-positive but nonetheless contracted rubella, leading to CRS in offspring [2-9]. To decrease CRS risk, a research group supported by the Japanese government has (since 2004) recommended rubella vaccination not only for those who are negative by $\mathrm{HI}$ assay (antibody titers $<1: 8$ ), but also for subjects with low titers $(\leq 1: 16)$. However, our previous study demonstrated that $42.6 \%$ of those with pre-vaccination HI antibody titers $\leq 1: 16$ again exhibited low titers $(\leq 1: 16)$ at two years after vaccination [10]. In addition, our previous study of cellular and humoral immunity in college students with low antibody titers [11] demonstrated that some subjects with positive but low antibody titers were negative in cell-mediated immunity (CMI) assays, which may explain why rubella reinfection can occur in seropositive individuals. Taillardet et al. showed that B cells that receive T-cell help generate antibody-secreting progeny cells that produce significantly more antibody than $\mathrm{B}$ cells that are activated by antigen in the absence of Tcell help [12].

The purpose of the present study was to further clarify associations between cellular and humoral immunity during the extended period of two years post-vaccination, a longer interval than the 6 to 8 weeks post-vaccination examined in our previous study [11]. The present 
study primarily reports the data at two years post-vaccination, but some data from the previous study are incorporated here to permit assessment of changes in antibody and interferon- $\gamma$ levels.

\section{Subjects and Methods}

The collection and use of human materials for the present study were approved by the Ethics Committee on Human Subjects of the Kawasaki Medical School (625-4), and in accordance with the ethical statements of the Declaration of Helsinki. Informed consent was obtained from each subject. The volunteers enrolled in this study comprised 64 healthy college students, each of whom was asked to present the school with written verification of their past history of vaccination.

Among the pool of 64 subjects, 38 individuals (Group 1) were newly enrolled from the 39 college students in the previous study [11], which examined rubella-specific cell-mediated and humoral immunity following vaccination in students with $\mathrm{HI}$ antibody titers $<1: 16$. As part of the previous study, these subjects had been vaccinated two years ago with a monovalent, live, attenuated rubella vaccine against the Matsuura strain (Biken, Osaka, Japan; Lot R1701). The remaining 26 students (Group 2) enrolled for this study corresponded to individuals who had shown HI antibody titers $\geq 1: 32$ when screened two years ago at the college. Group- 2 members were confirmed to be seronegative for IgM antibody against rubella virus at entry onto the present study. Samples from Groups 1 and 2 were assessed to determine the following parameters: general antibody levels using a hemagglutination-inhibition (HI) assay; IgM and IgG antibody levels by enzyme-linked immunosorbent assay (ELISA); and CMI against rubella virus using an interferon $-\gamma$ release assay.

\section{Antibodies against Rubella}

Anti-rubella antibody levels were measured using the HI assay kit (Denka Seiken, Tokyo, Japan) according to the manufacturer's instructions. HI antibody titers $<1: 8$ were defined as negative. The concentrations of $\operatorname{IgG}$ and $\operatorname{IgM}$ antibodies in sera were measured with an ELISA assay kit (Denka Seiken, Tokyo, Japan) according to the manufacturer's instructions.

\section{Interferon- $\gamma$ release assay}

The antigen used for the interferon- $\gamma$ release assay was the Bayler strain of rubella virus, provided as a suspension that contained $1.2 \times$ 107 plaque-forming units per dose prior to inactivation by ultraviolet radiation $\left(\right.$ at $\left.5,000 \mathrm{~J} / \mathrm{m}^{2}\right)$. The inactivated virus $(80 \mu \mathrm{L} /$ dose $)$ was added to heparinized whole blood $(800 \mu \mathrm{L})$ from each individual subject and the mixture was cultivated at $37^{\circ} \mathrm{C}$ for approximately $32-36 \mathrm{~h}$ to elicit the secretion of interferon- $\gamma$ from T-cells after recognition of the antigen. These co-cultivations were initiated within $2 \mathrm{~h}$ after the drawing of each blood samples. After incubation, the supernatants were collected, and interferon- $\gamma$ concentrations were quantified by ELISA (Human INF gamma Platinum ELISA, e-Bioscience, San Diego, $\mathrm{CA})$. For positive and negative control reactions, phytohemagglutinin (final concentration, $2.5 \mu \mathrm{g} / \mathrm{mL}$ in phosphate-buffered saline) and lysate after incubation without rubella virus, respectively, were added to the blood instead of antigen. The interferon- $\gamma$ values were calculated by subtracting values in negative control wells from values in antigenstimulated wells. The threshold (cut-off) was determined as mean +2 standard deviations (SDs) for seronegative subjects without a past history of vaccination or natural infection in our preliminary experiment.

\section{Statistical analysis}

Anti-rubella IgG antibody titers and interferon- $\gamma$ values over the 2 years of the study were compared using a two-tailed paired t test after logarithm-scale transformation. The correlation was performed using Spearman's rank correlation test. Comparisons of IgG antibody and interferon- $\gamma$ levels after vaccination among groups of CMI-positive, intermediate, and negative individuals were evaluated using a twotailed one-way ANOVA test with a post-hoc two-tailed unpaired t-test on data that had been subjected to logarithmic transformation. Differences with $\mathrm{p}<0.05$ were considered significant. For the statistical analyses, an IgG antibody titer of $<2.0$ index units was expressed as 1.0 index unit.

\section{Results}

\section{Characteristics of subjects}

The subjects' characteristics, which are summarized in Table 1, included history of vaccination and $\mathrm{HI}$ antibody titers in Group 1 at two years after vaccination and those at two years later in Group 2. These records of Group 1 regarding history of rubella vaccination showed that 8 students had been vaccinated once two years ago, and 26 had been vaccinated twice previously; 4 had been vaccinated at least once, given that vaccination history before the last vaccination was unknown. The time of last vaccination was more than 2 years ago for all of the subjects. The records of Group 2 regarding history of the vaccination revealed that one student had not been vaccinated before; 17 had been vaccinated once, more than two years ago; 2 had been vaccinated twice, more than two years ago; the vaccination history was not known for the remaining 6 subjects.

\begin{tabular}{|l|l|l|l|l|l|l|l|l|l|}
\hline \multicolumn{10}{|c|}{ Group 1 } \\
\hline History of vaccination & \multicolumn{10}{|l|}{ HI antibody titers at two years after vaccination } & $1: 1: 16$ & $1: 128$ & $1: 256$ & total \\
\hline & $<1: 8$ & $1: 8$ & $1: 16$ & $1: 32$ & 2 & 1 & 1 & 0 & 8 \\
\hline One dose & 0 & 1 & 3 & 9 & 3 & 1 & 1 & 0 & 26 \\
\hline Two doses & 1 & 11 & 1 & 2 & 0 & 0 & 0 & 4 \\
\hline At least one dose & 0 & 1 & 13 & 13 & 7 & 2 & 2 & 0 & 38 \\
\hline Total & 1 & & & & & & \\
\hline
\end{tabular}


Citation: Terada K, Hagihara K, Tanaka Y, Teranishi H, Oishi T, et al. (2017) Changes of Antibody Associated with Cell-Mediated Immunity in College Students During Two Years after Rubella Vaccination. J Vaccines Vaccin 8: 374. doi:10.4172/2157-7560.1000376

Page 3 of 8

\begin{tabular}{|c|c|c|c|c|c|c|c|c|}
\hline \multicolumn{9}{|c|}{ Group 2} \\
\hline \multirow[t]{2}{*}{ History of vaccination } & \multicolumn{8}{|c|}{$\mathrm{HI}$ antibody titers two years later } \\
\hline & $<1: 8$ & $1: 8$ & 1:16 & 1:32 & 1:64 & 1:128 & $1: 256$ & total \\
\hline No vaccination & 0 & 0 & 1 & 0 & 0 & 0 & 0 & 1 \\
\hline One dose & 0 & 0 & 1 & 10 & 3 & 1 & 2 & 17 \\
\hline Two doses & 0 & 0 & 0 & 1 & 1 & 0 & 0 & 2 \\
\hline Unknown & 0 & 0 & 4 & 1 & 0 & 1 & 0 & 6 \\
\hline Total & 0 & 0 & 6 & 12 & 4 & 2 & 2 & 26 \\
\hline
\end{tabular}

Table 1: Characteristics of the subjects classified by HI antibody titer. Group-1 subjects were vaccinated 2 years ago because of pre-existing HI antibody titers $\leq 1: 16$. Group-2 subjects were not vaccinated 2 years ago because of pre-existing HI antibody titers $\geq 1: 32$.

\section{Changes in antibody levels}

At approximately one month after vaccination, $31 / 38(81.6 \%)$ subjects in Group 1 (with pre-existing HI antibody titers $\leq 1: 16$ ) exhibited $\mathrm{HI}$ antibody titers $\geq 1: 32$, but titers remained $\geq 1: 32$ in $11 / 38$ (28.9\%) subjects at two years after vaccination, as shown in Table 2. In Group 2, in which individuals had HI antibody titers $\geq 1: 32$ two years previously, HI antibody titers remained $\geq 1: 32$ in $20 / 26(76.9 \%)$ subjects after two years without vaccination (Table 2).

\begin{tabular}{|l|l|l|l|l|l|}
\hline \multicolumn{5}{|l|}{ Pre-existing $\mathrm{HI}$ antibody } & \multicolumn{5}{l|}{ Two years after vaccination } \\
\hline Group 1 & $<1: 8$ & $1: 8$ & $1: 16$ & $\geq 1: 32$ \\
\hline$<1: 8$ & 8 & 1 & 1 & 1 & 5 \\
\hline $1: 8$ & 14 & 0 & 10 & 3 & 1 \\
\hline $1: 16$ & 16 & 0 & 2 & 9 & 5 \\
\hline Total & 38 & $1(2.6 \%)$ & $13(34.2 \%)$ & $13(34.2 \%)$ & $11(28.9 \%)$ \\
\hline & & two years later & & \\
\hline Group 2 & & $<1: 8$ & $1: 8$ & $1: 16$ & $\geq 1: 32$ \\
\hline$\geq 1: 32$ & 26 & 0 & 0 & $6(23.1 \%)$ & $20(76.9 \%)$ \\
\hline
\end{tabular}

Table 2: Changes in HI antibody titers at one month and two years after vaccination in Group 1, and during that two-year interval without vaccination in Group 2.
The IgG antibody titers in Group 1 decreased in the two years after vaccination, with values (mean $\pm \mathrm{SD}$ ) falling from $22.32 \pm 19.11$ to 8.89 \pm 8.16 index units $(\mathrm{p}<0.001)$. When the subjects were classified according to CMI status (negative, intermediate, or positive) at two years after vaccination, the IgG antibody values (mean $\pm \mathrm{SD}$ ) from one month after vaccination vs. two years after vaccination were $19.1 \pm$ 22.8 vs. $6.9 \pm 6.7$ ( $\mathrm{p}>0.05), 20.6 \pm 13.5$ vs. $7.3 \pm 5.5$ ( $\mathrm{p}=0.01)$, and $27.5 \pm$ 18.5 vs. $12.6 \pm 10.7$ index units $(\mathrm{p}<0.05)$, respectively, as shown in Figure 1. There were no significant differences in the antibody titers at 2 years after vaccination among the groups with CMI-positive, intermediate, or negative status in Group 1. Similarly, no significant change $(\mathrm{p}>0.05)$ in the antibody titers (mean $\pm \mathrm{SD}$ ) in Group 2 (with pre-existing $\mathrm{HI}$ antibody titers $>1: 32$ ) was observed from two years ago to present (54.45 \pm 63.43 vs. $59.11 \pm 81.4$ index units, respectively). When Group-2 subjects were classified based on CMI-negative, intermediate, or -positive status, the IgG antibody values (mean $\pm \mathrm{SD}$ ) from two years ago vs. present were $63.0 \pm 74.7$ vs. $59.6 \pm 79.8$ ( $\mathrm{p}>0.05), 43.1 \pm 40.3$ vs. $59.7 \pm 86.1$ ( $\mathrm{p}>0.05)$, and $60.4 \pm 72.5$ vs. $58.1 \pm$ 77.2 index units $(\mathrm{p}>0.05)$, respectively. Thus, there were not significant changes in the antibody titers during the 2 years among groups of CMI-positive, intermediate, and negative status in Group 2. 
Citation: Terada K, Hagihara K, Tanaka Y, Teranishi H, Oishi T, et al. (2017) Changes of Antibody Associated with Cell-Mediated Immunity in

\section{Fig. 1}

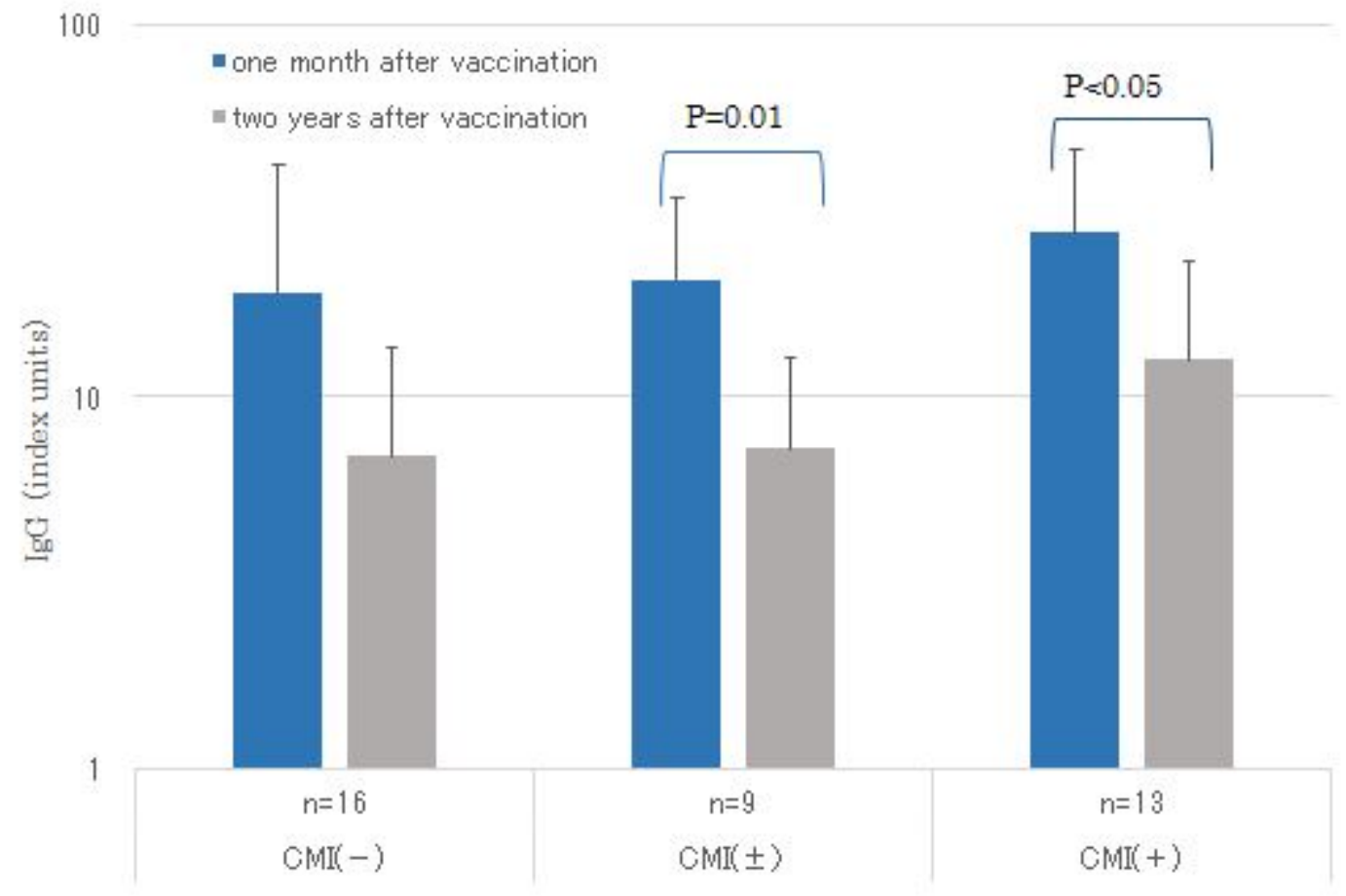

Figure 1: Changes in IgG antibody titers in subjects classified based on cell-mediated immunity (Data are presented as mean \pm SD. Changes in anti-rubella IgG antibody (ELISA) values at one month and two years after vaccination were compared using a two-tailed paired test after logarithm-scale transformation of the data. Comparison of the IgG antibody levels after vaccination among subjects with CMI-positive, intermediate, and negative status was performed by logarithmic transformation of the data, followed by a two-tailed ANOVA test with a post hoc two-tailed unpaired t-test).

The coefficient of correlation in IgG antibody titers in Group 1 was $0.385(\mathrm{p}<0.02)$ between pre-vaccination and one month after vaccination, but 0.147 ( $>0.05)$ between pre-vaccination and two years after vaccination, and 0.139 ( $\mathrm{p}>0.05)$ between one month and two years after vaccination, as shown in Figure 2. In contrast, in Group 2 the coefficient of correlation in IgG antibody titers between two years ago and present was $0.85(\mathrm{p}<0.00001)$. 
Citation: Terada K, Hagihara K, Tanaka Y, Teranishi H, Oishi T, et al. (2017) Changes of Antibody Associated with Cell-Mediated Immunity in College Students During Two Years after Rubella Vaccination. J Vaccines Vaccin 8: 374. doi:10.4172/2157-7560.1000376

Page 5 of 8

Fig. 2

a) IgG antibody

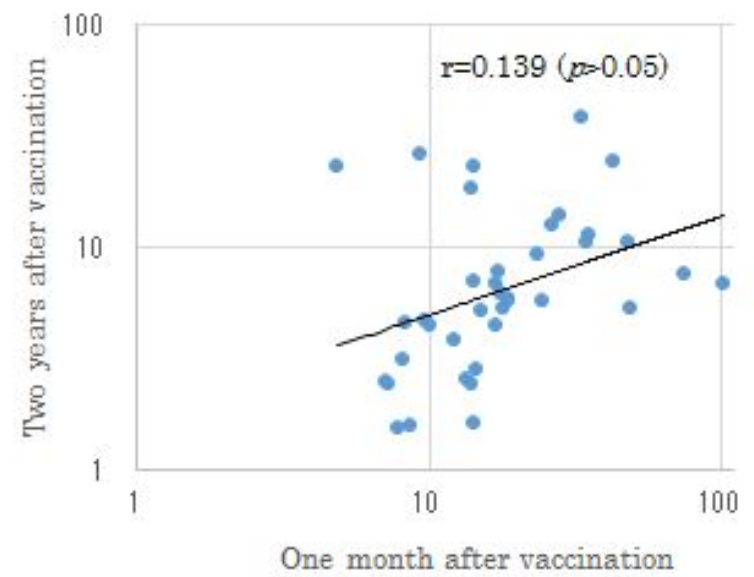

b) Interferon-y

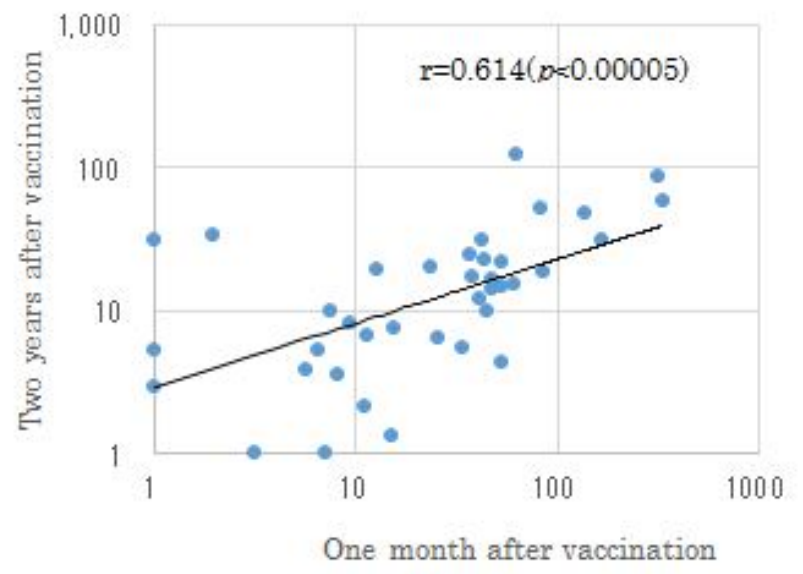

Figure 2: Coefficient of correlation in IgG antibody values and interferon- $\gamma$ titers between one month and two years after vaccination in Group 1 (The correlation was performed using Spearman's rank correlation test).

\section{Changes in interferon- $\gamma$ production}

Group-1 subjects exhibited CMI-positive status in 13/38 (34.2\%), $22 / 38(57.9 \%)$, and $13 / 38(34.2 \%)$ individuals at pre-vaccination, one month after vaccination, and two years after vaccination, respectively, as shown in Table 3. The interferon- $\gamma$ titers (mean \pm SD) decreased from $51.13 \pm 73.38$ to $20.98 \pm 24.79(\mathrm{p}<0.005)$ during the two years after vaccination. When Group-1 subjects were classified by CMInegative, intermediate, and positive status at two years following vaccination, the interferon $\gamma$ values (mean \pm SD) of one month $v s$. two years after vaccination were $13.3 \pm 13.8$ vs. $4.7 \pm 2.7(\mathrm{p}<0.05), 47.8 \pm$ 19.1 vs. $15.3 \pm 3.0(\mathrm{p}=0.001)$, and $99.9 \pm 109.9$ vs. $45.0 \pm 30.4 \mathrm{pg} / \mathrm{mL}$ $(\mathrm{p}>0.05)$, respectively (Fig. 3). The interferon $-\gamma$ values of the CMIpositive group at two years after vaccination were significantly higher than those of the CMI-intermediate group $(p<0.005)$ or those of the CMI-negative group $(\mathrm{p}<0.0005)$, as shown in Figure 3.

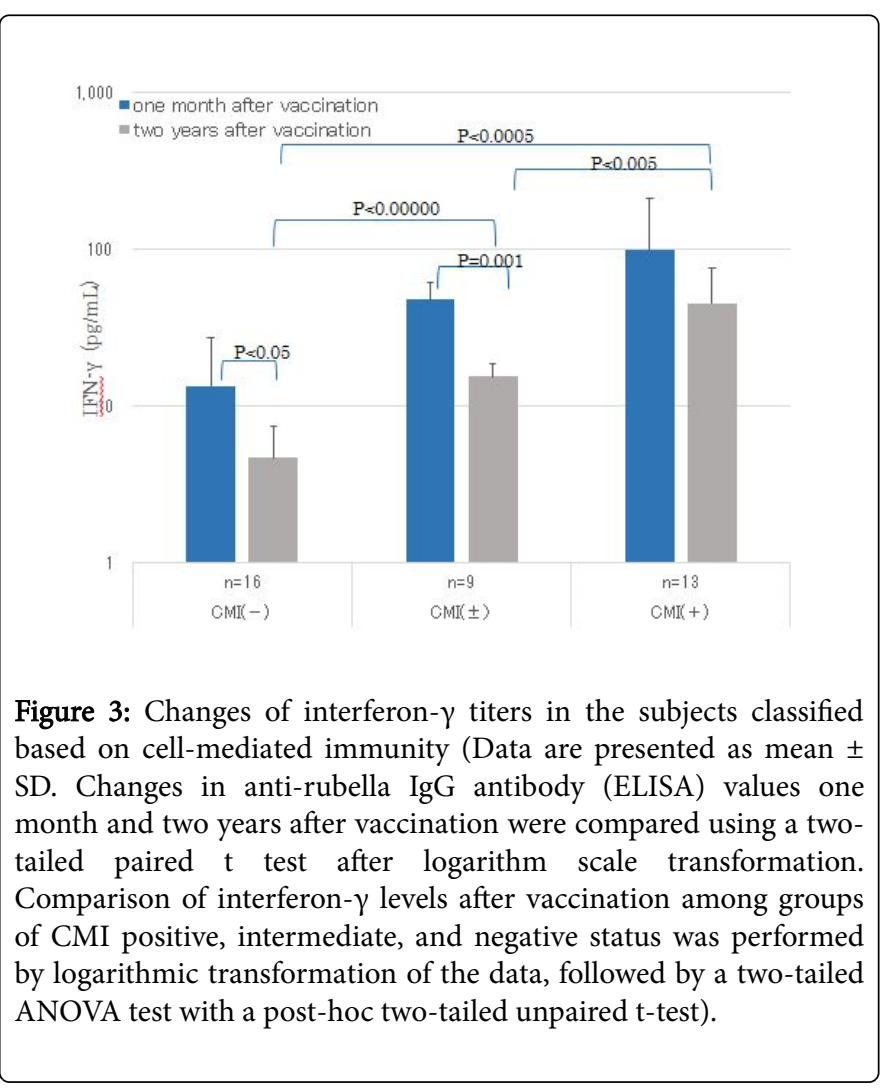


The coefficient of correlation in interferon- $\gamma$ titers in Group 1 was $0.848(\mathrm{p}<0.00001)$ between pre-vaccination and one month after vaccination, $0.504(\mathrm{p}<0.002)$ between pre-vaccination and two years after vaccination, and $0.614(\mathrm{p}<0.00005)$ between one month and two years after vaccination (Figure 2).

\begin{tabular}{|c|c|c|c|c|}
\hline Group 1 & & & & \\
\hline $\begin{array}{c}\text { IgG } \\
\text { antibody }\end{array}$ & & Negative & Intermediate & Positive \\
\hline $\mathrm{CMI}(-)$ & 16 & $2(12.5 \%)$ & $3(18.8 \%)$ & $11(68.8 \%)$ \\
\hline $\mathrm{CMI}( \pm)$ & 9 & $1(11.1 \%)$ & $3(33.3 \%)$ & $5(55.6 \%)$ \\
\hline $\mathrm{CMI}()$ & 13 & $0(0 \%)$ & $1(7.7 \%)$ & $12(92.3 \%)$ \\
\hline & 38 & 3 & 7 & 28 \\
\hline
\end{tabular}

Table 3: Changes in IgG antibody titers associated with cell-mediated immunity at 2 years after vaccination in Group 1 (Group-1 subjects were vaccinated 2 years ago because of pre-existing $\mathrm{HI}$ antibody titers $\leq 1: 16$ ).

\section{Association of antibody and interferon- $\gamma$}

When the Group-1 subjects were classified by CMI status at two years after vaccination, the IgG antibody-positive status was maintained in 12/13 (92.3\%) CMI-positive subjects, 5/9 (55.6\%) CMIintermediate subjects, and $11 / 16(68.8 \%)$ CMI-negative subjects during the two years post-vaccination, as shown in Table 3. Of the 11 subjects who were CMI-negative and antibody-positive at two years, 7 (63.6\%) had high antibody levels $(\geq 1: 32)$ at one month after vaccination. Additionally, when Group-1 subjects who were IgG antibody-negative at 2 years were classified by CMI status, none were CMI-positive, one was CMI-intermediate, and two were CMI-negative at two years after vaccination (Table 3). In contrast, Group-2 subjects who were originally antibody-positive remained antibody-positive two years later, regardless of CMI-positive or -negative status.

\section{Discussion}

Pre-existing virus-specific antibody represents the first line of defense against reinfection, but the best protection is likely to be elicited by a combination of strong humoral and cell-mediated immune responses. However, there have been few reports regarding the combination of humoral and cellular immunity against rubella [11,13-16]. The present study focused on the antibody changes associated with cellular immunity over a two-year interval following vaccination.

The interferon- $\gamma$ release assay focuses on interferon- $\gamma$ secretion by effector cells via T-cell memory, a process that is mediated almost entirely by CD4+ T-cells [17]. The interferon- $\gamma$ levels in Group 1 (subjects who had been vaccinated because pre-existing $\mathrm{HI}$ antibody titers were $\leq 1: 16$ ) decreased significantly at 2 years after vaccination. In addition, the proportions of patients in this group with CMInegative status at pre-vaccination, one month, and two years following vaccination were $42.1 \%, 28.9 \%$, and $42.1 \%$, respectively. Whereas, CMI negativity in Group 2 (subjects who exhibited pre-existing HI antibody titers $\geq 1: 32$ and therefore had not been vaccinated) was $26.9 \%$ at 2 years, but this value could not be compared to previous data, which was not collected. Nonetheless, CMI negativity was observed at a lower frequency in Group 2 than in Group 1. Even among Group-2 subjects with CMI-negative status, all showed HI antibody titers $\geq 1: 16$. The proportion of CMI-positive status among subjects with higher antibody levels (HI antibody titers $\geq 1: 32$ ) was higher than that in subjects with lower antibody levels (HI antibody titers $\leq 1: 16$ ). Thus, seropositive antibody status is thought to be maintained for a longer period in subjects with higher antibody levels, even in individual who are CMI-negative. In the present study, more than half of the subjects who were seropositive and CMI-negative had exhibited HI antibody levels $\geq 1: 32$ two years previously.

The antibody titers decreased significantly in Group 1, but did not decrease in Group 2. All of the previously seropositive subjects in Groups 1 and 2 remained seropositive at 2 years after vaccination. Kato et al. reported that $86 \%$ of previously seropositive hospital workers remained seropositive for over $3 \sim 5$ years [18]. However, previous studies have shown that antibody responses in humans do not reach steady levels until approximately $2 \sim 4$ years after infection or vaccination [19-21]. Therefore, the timing of the present study (2 years after vaccination) may have been too early to detect antibody levels in the steady period. However, the proportion of individuals with HI antibody titers $\leq 1: 16$ (the cut-off at which rubella vaccination is recommended in Japan) increased progressively over time in Group-1 subjects to $27 / 38(71.1 \%)$ at two years following vaccination from $7 / 38$ $(18.4 \%)$ at one month after vaccination. Our previous study [10] also demonstrated that proportion of individuals with $\mathrm{HI}$ antibody titers $\leq$ $1: 16$ increased from $11.5 \%(14 / 122)$ at one month following vaccination to $42.6 \%(52 / 122)$ at two years after vaccination. These observations are consistent with data indicating that, in cases with high levels of pre-existing antibody, booster vaccination provides only a temporary increase in antibody production, with antibody levels often declining to pre-booster-vaccination levels within 2 3 years [22]. In addition, $21(75 \%)$ of 28 subjects vaccinated twice in Group 1 exhibited HI antibody levels $\leq 1: 16$ at 2 years after the more recent vaccination, indicating that the second vaccination did not increase antibody titers to the levels that are recommended in Japan; this second vaccination is recommended worldwide. These data suggested that the recommended cut-off of HI antibody levels $\leq 1: 16$ for vaccination may not be a tight cut-off, given that many such subjects may need to be re-vaccinated every few years.

Correlation $(\mathrm{r}=0.504 \sim 0.848)$ of interferon- $\gamma$ levels in Group 1 was observed among subjects prior to study start, at one month postvaccination, and at 2 years post-vaccination. In contrast, unlike the interferon- $\gamma$ correlation of the antibody titers was not found between 2 years post-vaccination vs. prior to study start or between 2 years and one month after vaccination; only a weak correlation $(\mathrm{r}=0.385, \mathrm{p}<0.02)$ was found between prior to study start and one month after vaccination in Group 1. A much stronger correlation ( $\mathrm{r}=0.85$, $\mathrm{p}<0.00001$ ) was detected in Group 2 between two years ago and the present. This study demonstrated that the changes in antibody titer, in response to the booster effect of vaccination, apparently differed from changes in interferon- $\gamma$ levels. Immunity is often multifactorial; presumably other factors, beyond the booster effect of vaccination, influenced both humoral and cellular immune responses after vaccination.

Conversion from seropositive to seronegative antibody status in the 2 years after vaccination increased along with changes of CMI status from intermediate to negative. None, one, and two of the subjects with CMI-positive, intermediate, and negative statuses in Group 1 became antibody-negative at two years after vaccination, respectively. In contrast, seropositive status was retained in 10 of 11 subjects (91\%) 
that were CMI positive; compare that value to the $56 \sim 69 \%$ of CMIintermediate and negative subjects who remained seropositive during this two-year interval (Table 3). Humoral immunity is derived primarily from memory B cells, plasma cells, and memory T cells. All of the seronegative subjects in this study were thought to have memory B cells, because IgM antibody was not detected after vaccination. Thus, the factors important to the distinct responses would have to consist of plasma cells and/or memory $\mathrm{T}$ cells. In the plasma cell imprinted lifespan model, there are T-cell independent and dependent antibody responses [23]. Availability of helper $\mathrm{T}$ cells can have a profound impact on antibody response and on the function of plasma cells. Short-lived plasma cells are T-cell dependent and exhibit a lifespan of $1 \sim 3$ years [23]; thus changes in antibody levels during the first 2 years after vaccination, as seen in the present study, are likely to be associated with short-lived plasma cells.

Another factor associated with antibody response is the existence of genetic polymorphisms in the human leucocyte antigen (HLA) gene; a small number of specific HLA alleles are consistently associated with rubella-specific antibody titers $[24,25]$. Indeed, Kennedy et al. detected single nucleotide polymorphisms that are associated with variations in interferon- $\gamma$ secretion and map near the genes encoding butyrophilin and cytokine receptors [26,27].

In conclusion, antiviral protective immunity depends on the interplay between $\mathrm{T}$ cells and $\mathrm{B}$ cells to efficiently protect against disease. Therefore, the recommendation of rubella vaccination for individuals with $\mathrm{HI}$ antibody titers $\leq 1: 16$ is thought to be loose; an approach that incorporates CMI responsivity will be needed to enhance longer-persisting immunity against reinfection. Measurement of CMI against major viral diseases, like CMI against tuberculosis, will play an important role for estimation of the efficacy of vaccines and decisions regarding vaccination candidates in the future.

\section{Acknowledgments}

The authors wish to acknowledge Ms. Yuko Kanatani for her help in coordinating volunteers. This work was supported in part by a grant from the Kawasaki Medical School (24B-90), and by a grant from the Japanese Ministry of Education, Science, Sports and Culture.

\section{Disclosure}

The authors declare no conflict of interest.

\section{References}

1. http://idsc.nih.go.jp/disease/rubella/rubella.html (written in Japanese)

2. Hornstein L, Levy U, Fogel A (1988) Clinical rubella with virus transmission to the fetus in a pregnant woman considered to be immune. N Engl J Med 319: 1415-1416.

3. Best JM, Banatvala JE, Morgan-Capner P, Miller E (1989) Fetal infection after maternal reinfection with rubella: Criteria for defining reinfection. BMJ 299: 773-775.

4. Gilbert J, Kudesia G (1989) Fetal infection after maternal reinfection with rubella. BMJ 299: 1217.

5. Weber B, Enders G, Schlösser R, Wegerich B, Koenig R, et al. (1993) Congenital rubella syndrome after maternal reinfection. Infection 21 118-121.

6. Braun C, Kampa D, Fressle R, Willke E, Stahl M, et al. (1994) Congenital rubella syndrome despite repeated vaccination of the mother: A coincidence of vaccine failure with failure to vaccinate. Acta Paediatr 83: 674-677.
7. O'Shea S, Corbett KM, Barrow SM, Banatvala JE, Best JM (1994) Rubella reinfection; role of neutralizing antibodies and cell-mediated immunity. Clin Diagn Virol 2: 349-358.

8. Bullens D, Smets K, Vanhaesebrouck P (2000) Congenital rubella syndrome after maternal reinfection. Clin Pediatr (Phila) 39: 113-116.

9. Ushida M, Katow S, Furukawa S (2003) Congenital rubella syndrome due to infection after maternal antibody conversion with vaccine. Jpn J Infect Dis 56: 68-69.

10. Terada K, Akaike H, Ogita S, Ouchi K (2014) Long effect of a booster on rubella antibodies from each original HI titer following vaccination. Kansenshogaku Zasshi 88: 110-116.

11. Terada K, Itoh Y, Wakabayashi T, Teranishi H, Akaike H, et al. (2015) Rubella specific cell-mediated and humoral immunity following vaccination in college students with low antibody titers. Vaccine 33: 6093-6098.

12. Taillardet M, Haffar G, Mondière P, Asensio MJ, Gheit H, et al. (2009) The thymus-independent immunity conferred by a pneumococcal polysaccharide is mediated by long-lived plasma cells. Blood 114: 4432-4440.

13. Allmendinger J, Paradies F, Kamprad M, Richter T, Pustowoit B, et al. (2010) Determination of rubella virus-specific cell-mediated immunity using IFN gamma-ELISpot. J Med Virol 82: 335-340.

14. Tosh PK, Kennedy RB, Vierkant RA, Jacobson RM, Poland GA (2009) Correlation between rubella antibody levels and cytokine measures of cell-mediated immunity. Viral Immunol 22: 451-456.

15. Chaye HH, Mauracher CA, Tingle AJ, Gillam S (1992) Cellular and humoral immune responses to rubella virus structural proteins E1, E2, and C. J Clin Microbiol 30: 2323-2329.

16. Toyoda M, Ihara T, Nakano T, Ito M, Kamiya H (1999) Expression of interleukin-2 receptor alpha and CD45RO antigen on $\mathrm{T}$ lymphocytes cultured with rubella virus antigen, compared with humoral immunity in rubella vaccines. Vaccine 17: 2051-2058.

17. Otani N, Baba K, Okuno T (2009) Interferon-gamma release assay: A simple method for detection of varicella-zoster virus-specific cellmediated immunity. J Immuno Methods 351: 71-74.

18. Kato H, Mori M, Oba M, Kawahara H, Kaneko T (2016) Persistence and Half-lives of Anti-measles and Anti-rubella Antibodies in Japanese Hospital Workers: A Longitudinal Study. Intern Med 55: 2587-2594.

19. Lee MS, Chien LJ, Yueh YY, Lu CF (2001) Measles seroepidemiology and decay rate of vaccine-induced measles IgG titers in Taiwan, 1995-1997. Vaccine 19: 4644-4651.

20. Herrmann KL, Halstead SB, Wiebenga NH (1982) Rubella antibody persistence after immunization. JAMA 247: 193-196.

21. Terada $\mathrm{K}$, Inoue $\mathrm{M}$, Wakabayashi T, Akaike H, Ogita $\mathrm{S}$, et al. (2011) Natural alteration of antibody titers in a patient with immunoglobulin A deficiency after chickenpox over a 10-year period. Pediatr Int 53: 1075-1077.

22. Amanna IJ, Carlson NE, Slifka MK (2007) Duration of humoral immunity to common viral and vaccine antigens. N Engl J Med 357: 1903-1915.

23. Amanna IJ, Slifka MK (2010) Mechanisms that determine plasma cell lifespan and the duration of humoral immunity. Immunol Rev 236: 125-1238.

24. Ovsyannikova IG, Pankratz VS, Larrabee BR, Jacobson RM, Poland GA (2014) HLA genotypes and rubella vaccine immune response: additional evidence. Vaccine 32: 4206-4213.

25. Lambert ND, Haralambieva IH, Kennedy RB, Ovsyannikova IG, Pankratz VS, et al. (2015) Polymorphisms in HLA-DPB1 are associated with differences in rubella virus-specific humoral immunity after vaccination. J Infect Dis 211: 898-905.

26. Kennedy RB, Ovsyannikova IG, Haralambieva IH, Lambert ND, Pankratz VS, et al. (2014) Genome-wide SNP associations with rubella-specific cytokine responses in measles-mumps-rubella vaccine recipients. Immunogenetics 66: 493-499. 
Citation: Terada K, Hagihara K, Tanaka Y, Teranishi H, Oishi T, et al. (2017) Changes of Antibody Associated with Cell-Mediated Immunity in College Students During Two Years after Rubella Vaccination. J Vaccines Vaccin 8: 374. doi:10.4172/2157-7560.1000376

Page 8 of 8

27. Kennedy RB, Ovsyannikova IG, Haralambieva IH, Lambert ND, Pankratz VS, et al. (2014) Genetic polymorphisms associated with rubella virus- specific cellular immunity following MMR vaccination. Hum Genet 133: 1407-1417. 